\title{
Arkadiusz Stempin
}

Tischner European University, Cracow

\section{THE IMPERIAL GERMAN BOARD OF ARCHIVES \\ IN WARSAW: A PARADIGMATIC EXAMPLE OF THE 'MORAL CONQUEST' POLICY IN THE POLISH TERRITORY DURING THE FIRST WORLD WAR}

The exemplary activity of German science is clearly for the benefit of this occupied country. We can be proud of what has been achieved in this war by the German strength and the German spirit.

Adolf Warschauer ${ }^{1}$

In dubious situations, the interest of Prussia must take primacy over that of Poland.

Paul Kehr ${ }^{2}$

\begin{abstract}
The essay analyses the activities of the imperial German Board of Archives as a form through which the 'moral conquest' (moralische Eroberung) policy was pursued in Congress Poland by the German Empire in the First World War years. Central to the argument is not only the aspect of a model incarnation of a soft-power strategy in exportation of German science to a conquered country, this being a key instrument of the peaceful conquest of Poland, but also an organic incoherence of the strategy, as reflected in the way the Polish archives were managed. Such

${ }^{1}$ Adolf Warschauer, 'Deutsche Archivverwaltung in Polen', Korrespondenzblatt des Gesamtvereins der Deutschen Geschichts- und Alterthumsvereine, lxiv, 9-10 (1916), 247. Adolf Warschauer (1855-1930) was in 1915-18 Director of the GGW's German Archival Board. Before then (1903), he joined the Posen Academy's Faculty of History as a Dozent, and was Director of the State Archives of Danzig (1912).

2 Stefan Lehr, 'Die “Rückforderung” polnischer Archivalien', in Dietmar Neutatz and Volker Zimmermann (eds.), Die Deutschen und das östliche Europa. Aspekte einer vielfältigen Beziehungsgeschichte (Essen, 2006), 50. Paul Friedolin Kehr (1860-1944) was Director General of the Prussian State Archives (1915-29), and Director of the Kaiser-Wilhelm-Institut's Historical Department (1917-41).
\end{abstract}


identification suggests that the German Empire pursued in Congress Poland activities typical of semicolonial policies. For one thing, the German administrators safeguarded against destruction the official (public, state-related) documents and archival collections abandoned by the Russians, catalogued them and made them available to historians, in a professional way and on civilised terms. Otherwise, in pursuance of their particular interests, the German authorities of the General Government of Warsaw endeavoured, from a position of strength, to take over the valuable documents from the Polish archives. This venture negated, in the perception of the Polish partners, the esteem for Germany and its civilizational achievements, administering a final blow to the 'moral conquest' concept.

Keywords: archives, occupation(al) administration, moral conquest, civilizational mission, General Hans Hartwig von Beseler

With the military successes of the German Empire on the Eastern Front and the displacement of the tsarist army from the Congress Poland territory, which was completed in the summer of 1915, it was resolved in Berlin that a territorial unit, which is known today as the Generalgouvernement Warschau (GGW), be established in the conquered area that formed the warfront's supply network. The openended outcome of the war determined the formation's temporary nature. Strongly influenced by the campaigning of General Hans Hartwig von Beseler, the Governor-General, the decision-makers of German foreign policy coined the idea that the Congress Poland territory should be made a sovereign state allied with the German Empire based on economic, military, and cultural bonds, thus forming part of the German Mitteleuropa, ready for further inevitable wrestle with the Romanov Empire. ${ }^{3}$

Beseler thus fit in the politics which the Berlin-based quartermasters of foreign agenda briefly described, shortly before the outbreak of the First World War, as a moralische Eroberung. The doctrine assumed that measures other than military may be used with respect to another country, thus enabling to increase the prevalence of the dominant power, weaken the country's resolve, or make it totally dependent. Such 'moral capture', or 'moral conquest', with its prevalent focus on 'peaceful expansionism', would be brought about

${ }^{3}$ For more on von Beseler's (1851-1921) activities in Warsaw, see Arkadiusz Stempin, 'Generał-pułkownik Hans Hartwig von Beseler - generalny gubernator warszawski w latach 1915-1918', Dzieje Najnowsze, xliii, 3 (2011), 21-34. 
through school, language, religion, and - subsequently - arts, literature, and science. ${ }^{4}$

Taking this interpretation into account, this essay analyses the activities of the Imperial German Board of Archives as a means of implementation of the moralische Eroberung policy in Congress Poland by the conquerors. Apart from an instance of model operationalisation of the soft power strategy in the exportation of German science to the conquered country, the core of the argument extends to identifying an organic incoherence of the said strategy, as reflected in the management of Polish archives. This observation would imply that the German Empire pursued in Congress Poland activities characteristic of semicolonial policy.

In operation from 1915 to 1918, the German Board of Archives has attracted no special attention among historians, whether Polish or German, although its Director, Adolf Warschauer, himself offered a valuable point of departure as he submitted a synthetic description, being a subjective view, of the structure he managed. ${ }^{5}$ This and his subsequent books, written on the spot, in the first years following the abrupt collapse of the German rule in Poland in November $1918,{ }^{6}$ joined the multiple memoirist pieces published at that time in Europe. ${ }^{7}$ Such was Warschauer's intention as well: like the other

${ }^{4}$ See Jürgen Kloosterhuis, 'Friedliche Imperialisten'. Deutsche Auslandsvereine und auswärtige Kulturpolitik, 1906-1918 (Frankfurt am Main, 1994), 3-58.

${ }^{5}$ Adolf Warschauer, Geschichte der Archivverwaltung bei dem Deutschen Generalgouvernement Warschau (Berlin, 1919). The study referred to the publications issued while the Warsaw Board of Archives was still in operation: idem, 'Deutsche Archivverwaltung', 246-7; idem, 'Die Deutsche Archivverwaltung in Warschau', Korrespondenzblatt des Gesamtvereins der Deutschen Geschichts- und Alterthumsvereine, lxv, 3-4 (1917), 96-101; idem, 'Die neue Archivordnung für das Königreich Polen', Korrespondenzblatt des Gesamtvereins der Deutschen Geschichts- und Alterthumsvereine, lxvi, 9-10 (1918), 228-31; Die Preußischen Registraturen in den polnischen Staatsarchiven: fasc. 1: Die Geschichte der preußischen Registraturen, fasc. 2: Der Bestand der Berliner Zentralregistraturen (Veröffentlichungen der Archiv-Verwaltung bei dem Kaiserlich-Deutschen Generalgouvernement Warschau, 2, Warschau, 1918).

${ }^{6}$ Apart from the Warschauer study, the following were published: idem, 'Erinnerungen aus Warschau', Historische Monatsblätter für die Provinz Posen, xx, 1 (1919), 65-76; idem, Deutsche Kulturarbeit in der Ostmark. Erinnerungen aus vier Jahrzehnten (Berlin, 1926).

${ }^{7}$ See Hans-Erich Volkmann, 'Gesellschaft und Militär am Ende des Ersten und des Zweiten Weltkriegs', in Bruno Thoss and Hans-Erich Volkmann (eds.), Erster Weltkrieg, Zweiter Weltkrieg. Ein Vergleich: Krieg, Kriegserlebnis, Kriegserfahrung 
prominent administrators of the GGW, he felt compelled to put his thoughts into writing. However, compared to the publications by other decision-makers, ${ }^{8}$ Warschauer's studies were highly unbiased. Three factors were underlying: (i) his profession as a historian; (ii) his personal moral habitus; and, (iii) the matter he described. The activities pursued by the German Board of Archives implied a number of aspects beneficial to the other party, that is, to Poland.

This positive side was appreciated by Kazimierz Kaczmarczyk (1878-1966), Polish historian and Director of the Archives in Poznań. In the period of growing political tension between the Weimar Republic and the Second Republic of Poland, he did not hesitate to talk appreciatively of the activities pursued during the First World War by the German archivists' team led by Warschauer. ${ }^{9}$

in Deutschland (Paderborn et al., 2002), 841-72, here: 843; Klaus-Jürgen Müller, 'Deutsches und Französisches Militär nach den beiden Weltkriegen', in Ilja Mieck and Pierre Guillen (eds.), Nachkriegsgesellschaften in Deutschland und Frankreich im 20. Jahrhundert (München, 1998), 263-82.

${ }^{8}$ To mention, on an exemplary basis: Paul Roth [in charge of GGW's press policy], Die politische Entwicklung in Kongresspolen während der deutschen Okkupation (Leipzig 1919), 5-139, 182-91; Wilhelm Stein [P. Roth's associate], Die politische Entwicklung im polnischen Judentum während der Zeit der deutschen Okkupation, in ibidem, 140-81; Bruno Geissler [a Protestant pastor in Lodz], ' $\mathrm{Zu}$ unserem Abschied von Polen', Evangelische Diaspora. Monatshefte des Gustav-Adolf-Verein, i (1919/20), 11-17; Adolf Eichler [head of a German Nationalbund in Lodz], Zwischen den Fronten. Kriegsaufzeichnungen eines Lodzer Deutschen (Lodz, 1918); Georg Cleinow [head of Press Section], Der Verlust der Ostmark (Berlin, 1934). A multivolume work on the GGW, submitted for print by Wolfgang von Kries, head of the Civil Board, has never seen the light of day; Bundesarchiv Koblenz, Nachlass Wolfgang von Kries, no. 710 .

${ }^{9}$ See Kazimierz Kaczmarczyk, 'Działalność niemieckiego zarządu archiwalnego w latach 1915-1918', Archiwum Komisji Historycznej Akademii Umiejętności, i (xii) (1923), 114-23, here: 123; idem, 'Adolf Warschauer', Roczniki Historyczne, vii (1931), 159-62; Eugeniusz Barwiński, 'Archivverwaltung beim Kais[erlichen] Deutschen Generalgouvernement Warschau', Kwartalnik Historyczny (1917), 560-1. Warschauer endeavoured to act in a conciliatory manner in the field of science as well. A few original records he found at the Archives of Historical Records inspired him to write an essay on the national identity of Copernicus. Whilst avoiding a definite opinion, he demonstrated the infertility of the historical German-Polish dispute around the great astronomer's nationality, he instead emphasised how fertilising this man's activities were for science and arts in both nations; see Adolf Warschauer, 'Die Geschichte des Streits um die Nationalität des Kopernikus', Mitteilungen der Historischen Gesellschaft für Posen, 1 (1925), 1-25. 
Kaczmarczyk wrote an article based on a now-perished, voluminous source material that was produced in 1915-18 by the Archives Board in Warsaw but got lost then on, in the abyss of the Second World War. ${ }^{10}$ This circumstance caused that historians have so far tended to give the German Archives Board a wide berth. ${ }^{11}$ Among Polish historians, the methodological difficulties coincided with the political factor. In the Cold War realities, historians active in communist Poland could propose no positive evaluation of German political actors of the Hohenzollern empire's time. It was only in the second decade after the 1989/90 transition that the activities of the German Board of Archives was subjected to historical analysis. The author of this words has identified the Board's Director as the closest associate of General von Beseler's in the GGW; ${ }^{12}$ Stefan Lehr wrote a study on Warschauer and the Archives Board. Central to the latter is a dispute with Polish historians over the ownership of archival materials generated in the South East Prussia and New East Prussia (Süd-/Neuostpreußen) between 1793 and 1806, which resulting from the Tilsit Treaties of 1807 were transferred to the Duchy of Warsaw. As Lehr aptly concludes, the criteria employed by the German party to the dispute, based whereon they have put forth their claims, were ambiguous: they referred to complementariness of archives, to the territorial principle, or else, to the records' original provenance. ${ }^{13}$

${ }^{10}$ A lion's share of the files of the German Board of Archives, stored at the Archives of Modern Records in Warsaw, was consumed by fire as part of a retaliation action launched by Heinrich Himmler for the causing of the Warsaw Rising in August 1944; see Józef Stojanowski, 'Archiwum Akt Nowych w Warszawie', in Straty archiwów $i$ bibliotek warszawskich $w$ zakresie rękopiśmiennych źródet historycznych, ii: Kazimierz Konarski (ed.), Archiwa porozbiorowe i najnowsze (Warszawa, 1956), $265 \mathrm{ff}$. The other part of the files, which had been hidden by the Poles at the Sokolnicki Fort, to be rescued from the Germans entering Warsaw in September 1939, was found by the Germans and taken away to Potsdam (see ibidem, 238), where the records were eventually destroyed by fire resulting from the Allied Forces' bombing in spring 1945.

${ }^{11}$ A prominent example is the altered profile of a dissertation: occupationrelated policies in Poland into Berlin's diplomatic policies toward Poland, being the case with Werner Conze, Polnische Nation und deutsche Politik im Ersten Weltkrieg (Köln and Graz, 1958).

${ }^{12}$ See Arkadiusz Stempin, Próba 'moralnego podboju' Polski przez cesarstwo niemieckie w latach I wojny światowej (Warszawa, 2014).

${ }^{13}$ See Lehr, 'Die "Rückforderung”', 47-66. 


\section{GENERAL HANS H. VON BESELER'S MORAL CONQUEST POLICY}

Beseler, who appeared in Warsaw as a thorough dilettante in Polish affairs, pretty quickly came to understanding that by merely administering the territory under occupation, he would not win Poles over as prospective allies in the formation of a common anti-Russian front. Given the fact that no clearly defined future of the Polish lands under occupation had been decided in Berlin, he resolved to grant his subjects a number of concessions in the area of culture and national symbolism, which came across their national aspirations. Thereby, he incarnated the paradigm of occupational rule, which, "using soft and camouflaged means of violence", impose "recognition of its authority" and "confirmation of the mandate to exercise the power". ${ }^{14}$ Legitimation of authority in an alien country is founded not only upon the ruler's will to rule but also on the readiness of the governed to accept such power and authority. An attitude of this sort is generable by submitting interesting offerings to the governed community, so as to arouse among them appropriate response, with inherent readiness to cooperate. ${ }^{15}$ This strategy was characteristic of semicolonial policy, and tested before the war by the German Empire with respect to the Ottoman Empire (in the Balkans) as well as the Chinese colony. ${ }^{16}$

${ }^{14}$ Pierre Bourdieu, Practical Reason: On the Theory of Action (Stanford, 1998), 56.

${ }^{15}$ See Klaus Mühlhahn, Herrschaft und Widerstand in der 'Musterkolonie' Kiautschou. Interaktionen zwischen China und Deutschland 1897-1914 (München, 2000), 240.

${ }^{16}$ The semicolonial policy pursued by the German Empire with respect to the Ottoman Empire in the Balkans took advantage of the fact that the Balkan region, situated between the civilisation of the East and that of the West, was culturally retarded, which met the underlying condition for implementation of a semicolonial strategy. See Maria Todorova, Imagining the Balkans (New York, 1997). For semicolonial policies in China, see Klaus Mühlhahn, Herrschaft und Widerstand. The model of semicolonial policy, based on the northern delta of the Great River, is exemplified in a study by Kathy Lemons Walker, Chinese Modernity and the Peasant Path: Semicolonialism in the Northern Yangzi Delta (Stanford, 1999). Another circumstance conditional for the emergence of the colonial empire-colony relation was determined by the difference between the appearance in colonies of a hierarchy based on the criterion of race, ethnicity/nationality, and social class, and the existence of just the latter two categories in Western Europe's colonial countries. See Walter Mignolo, Local Histories - Global Designs. Coloniality, Subaltern Knowledges, and Border Thinking (Princeton, 2000), 36. The eastern peripheries of Europe, Russia 
In China and Turkey, as part of the moral capture strategy, politicalcultural projects were mainly pushed forward in the area of extension of university contacts and strengthening the German education and school system in the diaspora.

In the GGW, Beseler, together with political-and-cultural freedoms he granted, which abolished the rationing of uttering the national identity by Poles, implemented the German Empire's moral conquest policy. ${ }^{17}$ The catalogue of his concessions was quite appreciable. The reestablishment of a Warsaw University was the major step; in contrast to the period before 1914, when the university was deemed completely Russified, was now transferred to a team of Poles. ${ }^{18}$ A no less spectacular step Beseler made towards Poles was a consent for their commemoration of the 125th anniversary of the adoption of the Third-of-May Constitution (celebrated 3 May 1916). This opened the floodgates of permits for celebrating by Poles of a series of other national holidays and historical anniversaries, mainly with an antiRussian cutting edge. Moreover, the German authorities allowed the Polish language to be used in schools and GGW administration, as part of their political-cultural strategy; Prince Zdzisław Lubomirski,

- including Congress Poland (described in Germany as Russisch-Polen), and the south of Europe - including the Balkans, along with the Spanish empire, then undergoing a crisis, together with its Arabic heritage, were all perceived in Germany as not being part of the Western core of European civilisation. German historiographers have pretty recently attempted at (re)defining the phenomenon of colonialism; cf. Andreas Eckert, Kolonialismus (Frankfurt am Main, 2006); Jürgen Osterhammel, Kolonialismus. Geschichte, Formen, Folgen (München, 2003); Sebastian Conrad, Globalisierung und Nation im deutschen Kaiserreich (München, 2000) (including a chapter on Poland as a German colony: 'Deutschlands eigentliche Kolonie', 130-9).

${ }^{17}$ For the interrelation between the political/cultural sphere and foreign policies in modern international relations, which in fact, historically, follow up the said interrelation (thus identifiable as typical of a moral conquest policy), see Udo Metzinger, Hegemonie und Kultur: Die Rolle der kulturellen soft-power in der US-Außenpolitik (Frankfurt am Main et al., 2005).

${ }^{18}$ For more on the reactivation of the University of Warsaw by Beseler, see Bogdan Hutten-Czapski, 'Otwarcie Uniwersytetu Warszawskiego i Politechniki', in Krzysztof Dunin-Wąsowicz (ed.), Warszawa w pamiętnikach pierwszej wojny światowej (Warszawa, 1971), 387-9; Andrzej Garlicki and Andrzej Chojnowski, Dzieje Uniwersytetu Warszawskiego 1915-1939 (Warszawa, 1982); Arkadiusz Stempin, 'Die Wiedererrichtung einer polnischen Universität. Warschau unter deutschen Besatzung', in Trude Maurer (ed.), Kollegen, Kommilitonen, Kämpfer. Europäische Universitäten im Ersten Weltkrieg (Stuttgart, 2006), 127-46. 
a Pole to the core, was appointed Mayor of Warsaw. Beseler, moreover, approached Archbishop Aleksander Kakowski, the head of the Catholic Church in Congress Poland, who was much respected by his compatriots, with special deference. Beseler crowned his 'pro-Polish' political and cultural policy with a strictly political move - the Act of 5 November, a declaration proclaiming the formation of an independent Kingdom of Poland. ${ }^{19}$

The concessions made by the Governor-General did not translate into the expected effect on the Poles; they did not significantly reinforce pro-German sentiments, or provide sufficient incentives for cooperation, or even erode pro-Russian sympathies, for the pro-Polish trend in the area of culture interbred with the imperial interests of Germany. The latter implied economic pillaging of the GGW - with growing prices and dissatisfaction of the governed people - or disavowal of political postulates of Polish independence-oriented parties or factions, such as the formation of a Polish army under Polish chief command, or transferral of administrative functions within GGW to Polish hands. Otherwise, the administration-related regulations, which were intentionally meant to ensure security to the local people, exposed these people to intense oppression from the alien control apparatus. Thus, a squawking contradiction showed up, as characteristic of any semicolonial system, where a coercion strategy coexists with seduction strategies.

The incoherent policy of German occupation authorities with respect to Polish locals, analogous to any like semicolonial policy observable in late nineteenth and early twentieth century, is demonstrable also for the area controlled by the Imperial German Board of Archives.

II

THE BOARD OF ARCHIVES AS AN ELEMENT OF THE MORALISCHE EROBERUNG PROJECT

Having seized Warsaw in August 1915, the Germans came into possession of a large amount of Russian documents, left over by

${ }^{19}$ For a discussion of Beseler's appeasement policy applied in Warsaw in view of ensuring articulation of the national identity of Poles, see Krzysztof DuninWąsowicz, Warszawa w czasie pierwszej wojny światowej (Warszawa, 1974); Stempin, Próba 'moralnego podboju', 219-84. 
the stampeding Russians. ${ }^{20}$ Exposed to damage or loss in the war's realities, these documents called for being professionally protected. The takeover of the GGW administration forced the new administrators to preserve the existing personal and institutional records. Such a step could also be used to elegantly retort the charge of 'German barbarians' - the phrase the Allied Powers' propaganda unceasingly juggled with. ${ }^{21}$ Yet another aspect proved decisive in the tangle of benefits. Comprehensive protection of former Russian documents gave General von Beseler a vehicle that enabled him to energetically set about carrying out a mission civilisatrice in Poland and implanting the high culture of German organisation and science. Hence, three weeks after the General Government was established, Beseler resolved that a German unit be established to manage the archives. Efficient protection of not only former Russian documents but also Polish archive resources, with modern means being extended ever since to both categories, was meant, in Beseler's concept, to demonstrate the power of the achievements of German civilisation, attaining a propaganda effect among the educated and leadership strata of Polish society. ${ }^{22}$ As the Governor-General himself put it, the intent was to "light the torches of sciences, extinguished by Russians for long years, anew". ${ }^{23}$ Thus, a dreamful instrument would be created

${ }^{20}$ On leaving Warsaw, the Russians took away most of the archival documentation and registers, leaving in the city a handful of low-ranking officials charged with protecting the files and keeping them safe. In the Vladimir Fort, where the Russian military archive was kept, the German troops seized the Russian documents related to mobilisation. The soldiers, unaware of what they were dealing with, used the sheets of paper to make fire for cooking their foods. See Bogdan HuttenCzapski, Sechzig Jahre Politik und Gesellschaft (Berlin, 1936), ii, 223, 336. The documents found in Radom were robbed, for a change, and carried away to Poznań (then within Germany). On Beseler's intervention, these documents were later on returned to the Austro-Hungarian occupational authorities. See: Warsaw, Archiwum Akt Nowych [hereinafter: AAN], files: Provisional Council of State [Tymczasowa Rada Stanu (TRS)], no. 96, 'Protokół posiedzenia Komisji Przejściowej TRS, 13 września 1917' [Minutes of a meeting of the Transit Committee, Provisional Council of State], 31.

${ }^{21}$ For German wartime barbarism, see John Horne and Allan Kramer, German Atrocities, 1914: A History of Denial (New Haven, 2001).

${ }^{22}$ See Warschauer, 'Deutsche Archivverwaltung', 246.

${ }^{23}$ Freiburg im Br., Bundesarchiv, Militärarchiv [hereinafter: BA/MA Freiburg], N30/54, Beseler an A. Penck, 17 Nov. 1916. 
for a "Germany's fruitful cultural policy abroad", and for acquiring "international sympathy" - to use, this time, the phrases of Karl Lamprecht, cofounder of the 'moral conquest' idea. ${ }^{24}$ In today's terms, this would basically mean promotion of German science, demonstration of Germany's attractiveness as a powerful empire, in order to increase the country's prestige and influence in Poland. "If we do not yield to excessive ambition, Poland shall be ours, in some two or three generations' time", Beseler judged. ${ }^{25}$ His closest advisor in Warsaw, Count Bogdan Hutten-Czapski - the promoter of Polish-German rapprochement, who was extremely influential in Berlin - helped Beseler maintain the conviction that his design was legitimate. ${ }^{26}$

The formation of a German managing body for the archives required consent from the Prussian Ministry of State and Prussian state archives. Beseler requested Professor Paul Kehr, director with the latter, for "sending archivists to Warsaw with a command of Polish and Russian, who would be ready to inventory and investigate the local archival resources, whose condition is pitiful". The request was reinforced with use of a tactic argument remarking that the local archives comprise manuscripts of historical interest, priceless for German science, as they were related to the history of West Prussia and Poznań, and to the relationships between the Teutonic Order and Poland. ${ }^{27}$

Along with the Berlin-based chauvinist and military circles, otherwise reluctant toward the 'moral capture' concept, $\mathrm{Kehr}^{28}$ elevated Beseler's lure to the rank of German national interest. The archivists

${ }^{24}$ Karl Lamprecht, Über auswärtige Politik (Stuttgart, 1913), 14.

${ }^{25}$ BA/MA Freiburg, N30/15, 'Sitzung im AA. in Berlin vom 3. Oktober 1917'.

${ }^{26}$ See Hutten-Czapski, Sechzig Jahre, 263. Right after he arrived in Warsaw, Hutten-Czapski became acting as the number-one guard of the documents left over by the Russians. See AAN, TRS, no. 96, 'Protokół posiedzenia Komisji Przejściowej', 29. For more on Hutten-Czapski's activities in the GGW years, see Katarzyna Grysińska-Jarmuła, Hrabia Bogdan Hutten-Czapski (1851-1937). Żotnierz, polityk i dyplomata (Toruń, 2011).

${ }^{27}$ See Warsaw, Archiwum Główne Akt Dawnych [hereinafter: AGAD], 'KDGGW' files, no. 1, 'Bericht über die Entwicklung der Verwaltung des Generalgouvernements Warschau vom 23. Oktober 1915', no. 7; Kaczmarczyk, 'Działalność niemieckiego zarządu archiwalnego', 117.

${ }^{28}$ For more on Kehr, see Johanna Weiser, Geschichte der preußischen Archivverwaltung und ihrer Leiter. Von den Anfängen unter Staatskanzler von Hardenberg bis zur Auflösung im Jahre 1945 (Köln, 2000), 89. 
sent to Warsaw were to take over the Prussian archives. ${ }^{29}$ Thus, from the very beginning, with use of the magnetic force of German science and organisation, the moralische Eroberung, as a project for Warsaw, suffered severe detriment, with the mutually contradicting interests of two concepts, epitomised by the names of Beseler and Kehr, respectively. The latter regarded Adolf Warschauer as the most suitable man to take up the mission. ${ }^{30}$ Warschauer, until then director of the State Archives in Danzig, had a considerable portfolio to his credit, and was reputed as an outstanding expert in the history of Poland. ${ }^{31}$ Almost sixty-year-old man, a personality of "extensive humanistic learning", ${ }^{32}$ Warschauer, an experienced official, had first to dispel the doubts related to his age and a somewhat worrying health condition ${ }^{33}$ before he was put in office in Warsaw, on 11 October 1915, as Director of the Archives. He was furnished with fabulous emolument ${ }^{34}$ and an orderly to assist him, which attested to how privileged his office was, and that the rank of the organisation established in Warsaw was high. ${ }^{35}$ From the heights of his position, Kehr advised him that he "keep a watchful eye on the archives whose importance for Prussia is special", and to "deal carefully" with Poles. In any case, "in dubious

${ }^{29}$ See Lehr, 'Die "Rückforderung”, 49-50.

30 Julius Kohte, 'Adolf Warschauer zum Gedächtnis', Mitteilungen der historischen Gesellschaft für Posen, 3 (1935), 7-11.

${ }^{31}$ His main works included: Stadtbuch von Posen, i: Die mittelalterliche Magistratslinie. Die ältesten Protokollbücher und Rechnungen (1398-1433) (Sonderveröffentlichungen der Historischen Gesellschaft für die Provinz Posen, 1, Posen, 1892); Geschichte der Provinz Posen in polnischer Zeit (Posen, 1914); Geschichte der Stadt Gnesen (Posen, 1918). He also had a number of scientific articles published to his credit, as member of the Historische Gesellschaft für Posen and co-editor with the Historische Monatsblätter für die Provinz Posen.

${ }^{32}$ Hutten-Czapski, Sechzig Jahre, 265.

33 Warschauer was partly paralysed at the time, and therefore Beseler granted him with a special permit for his wife to accompany him while in Warsaw; otherwise, wives of German officials were not allowed to stay in GGW.

${ }^{34}$ Apart from his regular wage of 7,200 German marks, traineeship bonus (600 marks), annual residential facility refund (920 marks), he was entitled to 30 marks of per diem assistance; see Berlin, Bundesarchiv [hereinafter: BA-Berlin], RdI, no. 119685, 13, 'Präsident des Preußischen Staatsministeriums an Reichsamt des Inneren vom 29. November 1915'.

35 See BA-Berlin, RdI, no. 119685, 2, 'Präsident des Preußischen Staatsministeriums an Beseler vom 9. Oktober 1915’; BA-Berlin, RdI, no. 119685, 10, 'Beseler an Reichsamt des Inneren, 21. November 1915'. 
situations, the interest of Prussia must take primacy over that of Poland": such was the general guideline advised by Kehr, with which Warschauer arrived in the city on the Vistula. ${ }^{36}$

This was at odds with Beseler's commandment: the Governor instantly warned Warschauer against making use of even a smallest document from any of the Polish collections without his consent; he must not have any such piece sent to the Reich, Beseler remarked, also in case he has found that the Reich has the right to it. ${ }^{37}$ Thus, Beseler started his rule in Poland by strictly observing the Hague Convention which imposed on the occupying power the obligation to protect the archives in the conquered country. ${ }^{38}$ In order to force the director into absolute loyalty in face of the disagreement with the Berlin 'hawks', the chief administrator of the Generalgouvernement had him report directly to himself, rather than to the head of the GGW's Civil Board (the German central office handling civil affairs), or Kehr; Beseler moreover installed his plenipotentiary, Count Hutten-Czapski, a loyal votary of the 'moral conquest' scheme, to assist Warschauer. The organisational subordination of the latter to the military division was externally reflected by the obligation imposed on the historian to wear a military uniform on his official trips. ${ }^{39}$ Of higher relevance was, however, the fact that excepting Warschauer from the civil division aroused considerable consternation among the management team of GGW's Civil Board. ${ }^{40}$

${ }^{36}$ Lehr, 'Die "Rückforderung"', 50.

${ }^{37}$ See Warschauer, Deutsche Kulturarbeit, 271.

${ }^{38}$ In respect of the succession of Polish archives from the Russian resources, Beseler's stance was anchored in Article 56 of the rules-and-regulations annexed to the Fourth Hague Convention, 1907, which covered the 'laws and customs of war on land', providing that "the property ... of institutions dedicated to ... sciences, even when State property, shall be treated as private property", and forbidding "all seizure of, destruction or wilful damage done to institutions of this character, historic monuments, works of art and science, is forbidden", under pain of legal proceedings; cf. Journal of Laws, 1927, No. 21, Item 161. Since the presence of the Second Reich in the Polish territory was temporary, implying no incorporation in the German Empire, any other practice of takeover and distribution of archives, such as the ones applied in the aftermath of the German-Danish, German-Austrian, or German-French war, were irrelevant in that particular situation. See Thomas Fitschen, Das rechtliche Schicksal von staatlichen Akten und Archiven bei einem Wechsel der Herrschaft über Staatsgebiet (Baden-Baden, 2004), 87-92.

${ }^{39}$ Warschauer, Deutsche Kulturarbeit, 293.

${ }^{40}$ See BA-Berlin, RdI, no 119685, 8, 'Kries an Staatsekretär des Inneren vom 6. November 1915'. 
All this made the Warsaw archives board peculiar against its counterpart structures in German-occupied Belgium and France, which reported to the local civil administrations. ${ }^{41}$ Only with respect to science-related matters was the Archives Board director obligated to consult the director of the Prussian Archives. However, Beseler ensured in this way the best framework of action for his director, who could build a new structure without the necessity to bargain with the German bureaucracy in Warsaw. The Archivverwaltung beim Kaiserlichen Deutschen Generalgouvernement Warschau, which benefited from Beseler's personal support and assistance, was granted by him (on 11 February 1916) the right to use its own official seal, and furnished with a manual of authority. ${ }^{42}$ The latter confirmed the superior role of the Hague Convention in taking over the care of all the archives within GGW; Beseler was made the major instance in this respect, as he was the only one to resolve the disputable ownership of documents; the competencies of director of Prussian state archives (specifically, Kehr) were reduced to a scolarly consulting function; the Archives Board Director was afforded the right to render the collection available to German offices and researchers. Furthermore, archivists were obligated to search for non-public archives - those managed or held by municipalities, foundations, churches, or families - within the GGW area; the contents of these archives was subject to scholarly classification. Dissolution of the Archives Board would be the only premise for the Reich to take over all the files from Polish archives. ${ }^{43}$

Warschauer was obliged by Beseler to prepare every three months a report on the activities of the institution entrusted to him. The first such report, of which a total of thirteen were compiled by the end of the occupation, ${ }^{44}$ was submitted eight weeks after Warschauer assumed his office ${ }^{45}$; it specified in detail the Prussian manuscript

${ }^{41}$ See Weiser, Geschichte, 94.

${ }^{42}$ BA-Berlin, RdI, no. 199685, 42, 'Dienstanweisung für die Beamten der deutschen Archivverwaltung beim Kaiserlich Deutschen Generalgouvernement Warschau vom 11. Februar 1916'; Die Handschriften des Finanzarchivs zu Warschau. Zur Geschichte der Ostprovinzen des preußischen Staates, prefaced by Adolf Warschauer (Warszawa, 1917), 5.

43 Warschauer, Geschichte der Archivverwaltung, 10.

${ }^{44}$ On Beseler's instruction, each of the reports was issued in seventy-five copies and sent to selected officials, archives, and libraries in the Reich. See ibidem, 5 .

${ }^{45}$ See BA-Berlin, RdI, no. 119685, 20-5, 'Die wissenschaftliche Tätigkeit des Archivdirektors Dr. Warschauer, Bericht vom 7. Dezember 1915'. 
treasures deposited at the Warsaw archives. ${ }^{46}$ Beseler, contended at this point, personally took care about doing his part in acquiring the valuable information for Berlin; once there, the information started 'circulating its own way'. ${ }^{47}$ Glorified by his success, the general counted on a greater acceptance for his 'moral conquest' concept. But he was wrong, since the 'hawks' in Berlin focused even stronger on retrieving the Prussian archives completely - all the more so that Warschauer kept Kehr directly informed of the progress he was making in trailing these archives. As it may be judged from their extensive correspondence, ${ }^{48}$ the Director of the Archives Boards in Warsaw served two masters, Beseler and Kehr.

Not surprisingly, though for a different reason, Kehr satisfied Beseler's request to send over more archivists to Warsaw, as "the load of work exceeded the potential of an individual". ${ }^{49}$ The offer would extend to historians from Prussia, with a command of Polish and Russian and well-versed in the history of Poland. ${ }^{50} \mathrm{Kehr}$, excited at the prospect, must have forwarded Beseler's request with enthusiasm so great that the request circulated as far away as the Baden Ministry of Religions and Education. ${ }^{51}$ The linguistic and professional criteria were set quite high for the candidates, as attested by the rejection of application letters sent by some historians of renown, with no

${ }^{46}$ This concerned the general registries' collections, which had once flown out of the Berlin-based Ministry of State and Directorate-General for South Prussia and were considered lost.

${ }^{47}$ BA-Berlin, RdI, no. 119685, 28, 'Kaiserliches Deutsches Generalgouvernement Warschau an Reichsamt des Innern vom 6. Februar 1916'.

${ }^{48}$ See Lehr, 'Die "Rückforderung"', 51.

${ }^{49}$ Warschauer, Deutsche Kulturarbeit, 292.

${ }^{50}$ See BA-Berlin, RdI, no. 119685, 74, 'Kaiserlich Deutsches Generalgouvernement Warschau an Reichsamt des Inneren vom 19. April 1916'.

${ }^{51}$ See Freiburg, Universitätsarchiv, BO 38/58, 'Delbrück an das Ministerium des Großherzoglichen Hauses, der Justiz und des Auswärtigen in Karlsruhe vom 5. März 1916'. The Ministry, on its part, requested the University's Senate to present the appropriate candidates; see ibidem, 'Ministerium des Kultus und Unterrichts an den Senat der Freiburger Universität vom 13. März 1916'. In reply, the Senate proposed Professor Eckhardt for the purpose; see ibidem, 'Senat der AlbertLudwigs-Universität Freiburg an Ministerium des Kultus und Unterrichts vom 21. März 1916'. Eckhardt was, however, a philologist rather than a historian, and his command of Slavic languages was poor; hence, his candidacy was rejected; see BA-Berlin, RdI, no. 119685, 97 ff., 'Kaiserlich Deutsches Generalgouvernement Warschau an Reichsamt des Inneren vom 31. Mai 1916'. 
documented knowledge of Polish or acquaintance with the history of Poland..$^{52}$ As a result, three archivists were eventually deputed to Warsaw in early 1916, all of whom had met the rather unusual conditions (as far as Germany was concerned): Dr Walther Recke, ordered back from Danzig; ${ }^{53}$ Dr Hans Ferdinand Heinrich Bellée of the State Archives in Posen; ${ }^{54}$ and, Dr Otfried Schwarzer of the Municipal Library in Breslau. ${ }^{55}$ Together with Warschauer, they formed the core team of the Archives Board until its dissolution in November 1918.

These team took a cooperation offer from the Polish archivists Kazimierz Marcinkowski, by then Director of the Treasury Archive, and Maksymilian Baruch, a librarian with the Warsaw Society of History Lovers. ${ }^{56}$ These two Poles recognised that the German Board of Archives is driven by academic, rather than nationalistic, considerations. "An extremely industrious man, he obeyed my every single instruction", Warschauer said of Marcinkowski; "there was one exception, though: he would never cease the frequent cigarette smoking, dangerous due to possible ignition, during his business hours". ${ }^{57}$ This opinion might be considered a gauge of fruitful Polish-German scholarly collaboration, which could ignore the national resentments - and a first-step success story in terms of 'moral conquest'.

Warschauer took over the management of all the archives within GGW, except for the Central Archives and the Warsaw School District archive. The latter had had files of Poland's top school offices stored since 1807, and in 1915 was made part of the reopened University of Warsaw. ${ }^{58}$ The Russian archival system in Congress Poland embodied

52 See BA-Berlin, RdI, no. 119685, 74, 98, 'Kaiserlich Deutsches Generalgouvernement Warschau an Reichsamt des Inneren vom 19. April and 2. Juni 1916'.

${ }^{53}$ See BA-Berlin, RdI, no. 119685, 17, 'Kries an Königlich Preußische Archivverwaltung in Berlin, 10. Dezember 1915'.

${ }^{54}$ See BA-Berlin, RdI, no. 119685, 46, 54, 'Präsident des Preußischen Staatsministeriums an Reichsamt des Inneren vom 28. Februar and 22. März 1916'.

55 Warschauer, Deutsche Kulturarbeit, 282.

56 See Kaczmarczyk, 'Działalność niemieckiego zarządu archiwalnego', 117.

57 Warschauer, Deutsche Kulturarbeit, 286.

58 See Hutten-Czapski, Sechzig Jahre, 264. The University Archive was set up in 1915 and turned into an Archive of the Ministry of Religions and Public Education in April 1918. Its resource mainly consisted of the Warsaw School District registries left over by the Russians. Dr Józef Bieliński, a physician who was keen on history (without a formal background in this respect), was the only Pole to be acquainted with this particular resource. Therefore, after the Russians fled from 
a model, obsolete in Europe at that time, where the collections were archived based on pertinence and thematic unity of archival items. ${ }^{59}$ Such a system was diametrically different from the model functioning in the German Empire, whereby the resources had been put in the archive, since a hundred years ago, by provenance of sources (the place they were generated).$^{60}$ Hence, in line with the Russian manner, departmental archives functioned in Warsaw, including those related to courts-of-law, public prosecutor's office, or financial institutions. ${ }^{61}$ Documents generated by the central public administration were stored at a former Jesuit college. The headquarters of the German Board of Archives housed a Treasury Archive whose collection featured items from the pre-Partition period. The files dating to Russian Partition time, 1815-1915, were kept at the archive of the General-Governor, in the Generalgouvernement building, the military documents being stored in the military archive at the Vladimir Fort. Lastly, the Central Archives (Archives of Historical Records of the Kingdom of Poland) housed a number of valuable dossiers deposited from other archives, along with the so-called Crown and Lithuanian Metricas. The latter mentioned Archive was supervised by a dedicated team of scholars, and was the only one whose internal structure resembled that of the German archives.

With the outbreak of the war, the Central Archives was the only such institution in Warsaw not to have ceased its operation. While its Russian staff fled from Warsaw before the Germans entered, three Polish archivists, Director Teodor Wierzbowski among

Warsaw, the Central Civic Committee [Centralny Komitet Obywatelski, CKO] empowered him to take over those files and appointed him Director of the University Archive. With the establishment of the GGW, Bieliński reported to the officer for higher education, within the Civil Board. See Tadeusz Manteuffel, 'Archiwum Oświecenia Publicznego w Warszawie', in Straty archiwów i bibliotek warszawskich, ii, 211-33.

${ }^{59}$ See Fitschen, Das rechtliche Schicksal, 44.

${ }^{60}$ For the emergence and solidification of the source provenance principle, see Ernst Posner, 'Max Lehmann and the Genesis of the Principle of Provenance', in Ken Munden (ed.), Archives \& the Public Interest, Selected Essays by Ernst Posner (Washington, 1967), 36-44.

${ }^{61}$ The public prosecutor's office was tasked with providing a legal protection of public property. Hence, the files deposited at the Archive of the Public Prosecutor Office chiefly consisted of documents confirming the proprietary rights and taken advantage of in court trials and hearings. 
them, ${ }^{62}$ remained at their posts, now with no emolument, though. ${ }^{63}$ Under the altered regime, the Archive opened its doors again, ${ }^{64}$ and resumed scientific activities at the year's end. ${ }^{65}$ In contrast to the practices under the Russian rule, and in compliance with the standards binding in Prussia, the access was considerably facilitated. The institution thrived indeed: on a daily basis, at least ten historians pursued their queries there, ${ }^{66}$ an attendance rate equal to that of large German archives. Rendering the archives commonly available, under the banner of mission civilisatrice, displayed by General von Beseler in Warsaw, marked a cultural breakthrough in Poland.

Yet, this development was clouded by the service relationship between Warschauer and Wierzbowski. Although the Pole was ready to acknowledge his subordination to the Governor-General, he would not report to Warschauer: Wierzbowski argued he was older and higher-ranking than him, and "held the title of Excellency" ${ }^{67}$ As usual in such cases, the conflict was fomented by vanity and ambition, though the titles of Professor and Privy State Counsellor did appertain to Wierzbowski. ${ }^{68}$ His arguments finally convinced Beseler, which was not a doit on the part of the Governor but yet another proof of a conciliatory trend intended for the GGW. Beseler retained the status of Central Archives, and had Wierzbowski approved as an executive reporting directly to him, without Warschauer's supervision. ${ }^{69}$

${ }^{62}$ Climbing up the steps of career as a scholar, under the Russian auspices, Teodor Wierzbowski (1853-1923) crowned his path in 1889 with a professorship with the Warsaw University, whereat he lectured Polish literature (in Russian, since 1882). For this reason, he was not listed in 1915 as a University lecturer. See Cracow, Archiwum PAN [hereinafter: APAN - Kraków], dossier: 'Wierzbowski', no. 1882, ix, 35-40.

${ }^{63}$ They were obligated to stay, based on an instruction issued on 20 June 1915 by the Chairman of Polish Forensic Chamber; see APAN - Kraków, dossier 'Wierzbowski', no. 1882, vol. iii, 44 .

64 'Archiwum Główne w Warszawie. Lata 1915-1926', Archeion, ii (1927), 130.

${ }^{65}$ See Adam Stebelski, 'Archiwum Główne Akt Dawnych za dyrekcji Teodora Wierzbowskiego 1887-1919', in idem (ed.), Ksiega pamiatkowa 150-lecia Archiwum Głównego Akt Dawnych w Warszawie (Warszawa, 1956), 93.

${ }^{66}$ See AAN, 'Prezydium Rady Ministrów 1917/18', no. 17, 'Sprawozdanie Wierzbowskiego przedłożone polskiemu premierowi w dniu 15 października 1918'.

${ }^{67} \mathrm{Ibidem}$.

${ }^{68}$ See APAN - Kraków, dossier 'Wierzbowski', no. 1882, ix, 35-43.

${ }^{69}$ See APAN - Kraków, dossier: 'Wierzbowski', no. 1882, ix, 56, 'Beselers an Wierzbowski', 18. Okt. 1915. 
Moreover, the Governor assumed the cost of emolument for Polish members of the Archives staff ${ }^{70}$ as well as the expenditure related to the edition of the academically prestigious series 'Monumenta Iuris'. ${ }^{71}$ Before 1918, three volumes were published as part of the series in Polish, rather than in Russian, like before; a portion of copies of these publications appeared, for the first time ever, in German libraries, archives, and scientific societies.

All this did not diminish the personal dissonance between Wierzbowski and Warschauer. The former, who seriously took into consideration a fast return of the Russians to Congress Poland, considering himself a subject of the tsar, had sent to Moscow some priceless original copies, including Teutonic Order files, before the Germans took over. ${ }^{72}$ Inquired by German archivists about dispensing these documents, he replied evasively. Wierzbowski tended to avoid contacts with the Germans, ${ }^{73}$ and allowed them access to the Central Archives only if accompanied by a Polish archivist. ${ }^{74}$

\section{III}

MORALISCHE EROBERUNG IMPLEMENTED: THE ADMINISTRATIVE, SCIENTIFIC, AND POLITICAL-CULTURAL ASPECTS OF THE ARCHIVES BOARD'S ACTIVITIES

In order to avoid in the future any ambiguity with respect to the resources of Warsaw archives, Beseler ordained that all the collections taken over be made clear on the record, in a comprehensive fashion. ${ }^{75}$

${ }^{70}$ The extremely high salary Wierzbowski received under the Russian rule (7,000 roubles, of which 3,000 was the professor's wage and 4,000 was a special duty allowance as Archive Director) was taken over by the GGW authorities in its entirety; see Stebelski, 'Archiwum Główne Akt Dawnych', 90.

71 'Archiwum Główne w Warszawie', 131.

72 The list of files evacuated to Moscow itemised 200 diplomas on parchment documenting Polish-Teutonic relations, parliamentary ( $\mathrm{sejm}$ ) statutes dating to Congress Poland and displaying the tsar's signatures in hand, the civil servants' personal files, and portraits of the tsar; see 'Archiwum Główne w Warszawie', 131. Almost all of the documents dispatched by Wierzbowski were returned to Poland under the Treaty or Riga, 1921, as part of the vindication action.

${ }^{73}$ See APAN - Kraków, dossier 'Wierzbowski', no. 1882, ix, 218 ff.

${ }^{74}$ See Stebelski, 'Archiwum Główne Akt Dawnych', 96.

${ }^{75}$ See BA-Berlin, RdI, no. 119685, 31, 'Die Tätigkeit der Archivverwaltung in den Monaten Dezember 1915 und Januar 1916'; Warschauer, 'Deutsche Archivverwaltung', 246. 
The stocktaking, meticulously carried out under Warschauer's supervision, identified considerable gaps caused by the deportation of files and dossiers by the evacuating Russians.

A lion's share of the deficits included repertories and documents evidencing confiscations of Church properties. ${ }^{76}$ The protection of the archival resources exercised by the German team saved a number of files from damage or, possibly, robbery. Apart from the archives within the GGW, the protection extended to the registries ${ }^{77}$ and books left over unattended by the Russians, now weltering around in the edifices that earlier housed Russian administration agencies, or in private apartments leased by Russians. After these buildings or residential units were taken over by Germans or Poles, most of their new tenants had no idea about how valuable the Russian registries were.

There was one more reason behind the comprehensive protection applied to the entire archival resource in the GGW. Some Prussian officials and clerks, having established themselves in the General Government, did not resist the temptation to rob and confiscated documents, books, or works of art single-handedly. They considered their actions legitimate as they were mindful of the like practices of the arrogant and influential director of the Press Department with the GGW's Civil Board, Privy Counsellor Georg Cleinow, who had, for his part, successfully solicited an official legitimisation for those dealings from General Erich Ludendorff, head of the Ober Ost administration. It was on his initiative, among other things, that Ober Ost ordered, in spring 1915, the Russian archive in Kielce to be hastily transported to Posen before the Austro-Hungarian authorities could refute this move. ${ }^{78}$ But, a broad front was formed against the illegal evacuation of Polish cultural and art treasures to the Reich among the management team of the German civil administration headquarters in Warsaw, once the Board of Archives was enacted. Beseler banged his fist on the table and ordained that the robbed Kielce archive be transported back to where it belonged. In parallel, he set forth a new legal framework for handling the local cultural heritage: by means of an ordinance, dated 23 November 1915, in reference to the Hague Convention, the Governor-General protected and secured the archives,

76 See Warschauer, Deutsche Kulturarbeit, 286.

77 See idem, 'Einleitung', in Die Handschriften, 6.

78 See Hutten-Czapski, Sechzig Jahre, 264. 
libraries, works of science, and monuments of art, thereby suspending the carte blanche afforded before to Cleinow by the Ober Ost. ${ }^{79}$ Under another ordinance (of 3 April 1916), Beseler charged the German offices which have come into possession of the Russian registries with responsibility for their safekeeping. In the cases where these offices could not satisfy this requirement, the Board of Archives would provide assistance by depositing the documents in special fireresistant rooms of the Polish Bank, received from Beseler. ${ }^{80}$ The Board has also secured abandoned collections of books belonging to private persons or institutions, which oftentimes were regained afterwards by their previous owners. Interestingly, the German archivists were astonished at having learned that amidst the official Russian books tons of 'miserable novelettes' could be found: apparently, the tsarist civil servants occupied their time at the office reading the stuff. ${ }^{81}$

Apart from protecting and stocktaking of the archival materials, the institution run by Warschauer made it available for scientific purposes. Contrary, however, to the practice applied by the Russians before 1915, with the doors of the archives being opened to the 'chosen few' for bribe, ${ }^{82}$ the German Archives Board allowed broad access to archive collections. After all, one of the purposes behind the institution under discussion was to ensure the local scholars unrestrained access to the documents deposited in the archives, ${ }^{83}$ and this certainly increased the efficiency of historical research. On the other hand, this step has to be perceived, primarily, as modernisation of the archive-related practices previously prevalent in Poland - a process that was organically connected with Germany's mission civilisatrice in Congress Poland. ${ }^{84}$

${ }^{79}$ BA-Berlin, RdI, no. 199685, 42, 'Dienstanweisung für die Beamten'; HuttenCzapski, Sechzig Jahre, 264.

${ }^{80}$ See Warschauer, 'Einleitung', 6; idem, Die Geschichte der Archivverwaltung, 13 ff.

${ }^{81}$ See idem, Deutsche Kulturarbeit, 288.

82 The group of historians who were officially allowed before 1915 to pursue research or queries in Warsaw archives was quite scarce; most of them, one example being Marceli Handelsman, were perceived adversely by the Russians and never let inside. See Stefan Kieniewicz, 'Archiwum Skarbowe w Warszawie', in Straty archiwów $i$ bibliotek warszawskich, ii, 17-70, here: 19.

${ }^{83}$ See Freiburg, Universitätsarchiv, Bo 38/587, 'Delbrück an das Ministerium des Großherzoglichen Hauses, der Justiz und des Auswärtigen in Karlsruhe vom 5. März 1916'.

${ }^{84}$ Although the mission civilisatrice was basically employed to reinforce the authority in colonial countries, it did not remain confined to harness or enslave 
The Treasury Archive ${ }^{85}$ was the first one to open, in March 1916, with a considerable input from Kazimierz Marcinkowski. ${ }^{86}$ In August 1915, right after the German troops seized Warsaw, an eighty-plus years old servant named Ginter, veteran of the Russian-Turkish war, was found hidden at that same place. Born into a family of German colonists, the man spoke a fluent German, Polish, and Russian, and thus was immediately employed with the archive. ${ }^{87}$ The Treasury Archive stood out in the map of Warsaw archives, as its collection comprised almost one-and-a-half million of manuscripts, books, and cardboard-bound units, the oldest units being dated to late fifteenth century - including books of account, assignation registers, sejm accounts, vetting records, or customs accounts..$^{88}$ The extensive manuscript legacy was a collection of sources (of a unique quality) of use in a fiscal history of Poland, from the Middle Ages till the Partition. Therefore, Polish historians responded enthusiastically to the unrestrained access to archival materials, especially that, in duly substantiated cases, they could import manuscripts from other archives via the Treasury Archive. With no attendance data available for the latter, the opening of a second reading room for researchers soon after the first can be an indication. ${ }^{89}$ Hipolit Grynwaser, who worked on his monumental work on the gentry democracy in early Poland (Demokracja szlachecka), ${ }^{90}$ was among the very first historians to use the Archive's collection almost on a daily basis.

Almost immediately after the opening of the Treasury Archive, Warschauer started to build a reference library, entrusting its management to his daughter Anna, a librarian by training. The collection of indispensable encyclopaedias, handbooks, and classical works, which were pretty scarce in Warsaw, was meant to meet the expectations of the Archives Board employees as well as Polish scientists willing

the local communities, in one way or another, but elaborated its own operational agenda - as it were, in contraposition to the strengthening of the 'colonist's' power. See Mühlhahn, Herrschaft und Widerstand, $28 \mathrm{ff}$.

${ }^{85}$ See BA-Berlin, RdI, no. 119685, 86, 'Bericht über die Tätigkeit der Archivverwaltung in den Monaten Februar und März 1916'; Kaczmarczyk, 'Działalność niemieckiego zarządu archiwalnego', 116.

${ }^{86}$ See Warschauer, Deutsche Kulturarbeit, 286-7.

${ }^{87}$ See ibidem, 286.

${ }^{88}$ See idem, 'Einleitung'.

${ }^{89}$ See idem, Deutsche Kulturarbeit, 287.

${ }^{90}$ See Jerzy Maternicki, 'Warszawskie środowisko historyczne', in Warszawa w XIX wieku, 1795-1918, i (Warszawa, 1971), 201. 
to pursue their research with the Archive. ${ }^{91}$ Warschauer's designs reached even further, as the library was to become a 'generative cell' for a future Prussian-German historical institute to emerge one day in Warsaw. The idea was begotten at Warschauer and Kehr's first meeting in the late 1915 or early 1916 . Well aware of the rank of the valuable archival material deposited in Warsaw and related to the history of Prussian provinces, both historians cudgelled their brains over how to extend the life of the Board of Archives after the war comes to an end. A historical institute formula seemed the most appropriate, all the more so that Kehr could take advantage of his experience from the years when he made the German Historical Institute in Rome flourish. ${ }^{92}$ In line with this well-tested model, "German archivists were expected to carry out source-based queries in Poland, and offer assistance and support to German scholars arriving in this country to pursue historical research". ${ }^{93}$ On a parity basis, the same rights would be vested in Polish historians active in Germany. The German-Polish scientific collaboration offer was high on Kehr's agenda. ${ }^{94} \mathrm{He}$ discussed concrete steps in view of forging the long-range idea into action during his sojourn in Warsaw in May 1917. ${ }^{95}$ The planned deepening of contacts between German and Polish scientists and scholars was, in line with Karl Lamprecht's concept, a downright model instrument for 'fruit-bearing' foreign cultural policy focused on "winning friendly attitudes in foreign countries and contributing to a deeper mutual understanding". ${ }^{96}$ Thus, it would have been an organic element of

${ }^{91}$ See BA-Berlin, RdI, no. 119685, 'Bericht der Archiv-Verwaltung beim Generalgouvernement Warschau über ihre Tätigkeit in den Monaten April, Mai und Juni 1917'.

92 See Weiser, Geschichte, 92.

93 Warschauer, Deutsche Kulturarbeit, 292.

${ }^{94}$ See Kaczmarczyk, 'Działalność niemieckiego zarządu archiwalnego', 117. For a detailed discussion on the plans to open a historical institute in Warsaw and its counterpart institution in Berlin, against the background of the establishment of a historical institute within the Kaiser-Wilhelm-Gesellschaft, run by Kehr, and the institution's role, see Michèle Schubert, 'Zum Wirken Paul Fridolin Kehrs für ein deutsches historisches Zentralinstitut oder: Der lange Weg zum Kaiser-WilhelmInstitut für Deutsche Geschichte', in Bernhard von Brocke and Hubert Laitko (eds.), Die Kaiser-Wilhelm/Max Planck Gesellschaft und ihre Institute (Berlin and New York, 1996); Stefan Lehr, 'Pläne für ein Deutsches Historisches Institut in Warschau im Ersten Weltkrieg', Zeitschrift für Ostmitteleuropa-Forschung, lvi, 4 (2007), 594-602.

95 Warschauer, Deutsche Kulturarbeit, 307.

96 See Lamprecht, Über auswärtige Politik, 14. 
the classical moral capture programme. Besides, the German offer of collaboration in historical research opened for the Polish historical science an opportunity to upgrade the management of the archives and popularise the collections through making them broadly available; in a pretty apparent manner, this trend implied admitting Poland to participate in the civilizational achievements of Western Europe by transmitting them by Germany to its younger partner as part of the mission civilisatrice trend.

While Kehr's daring plans did not translate into action until the end of the German rule in Poland, Warschauer worked with unbelievable commitment (as Polish historian Kazimierz Kaczmarczyk emphasised after the war finished) on the development of the 'generative cell' for Warsaw's German Historical Institute project, amassing an impressive collection of some 300 key works covering the history of Poland and German-Polish relations, plus editions of source materials. Their previous editions had mostly been sold out and were considered 'white elephants', one example being the Monumenta Poloniae penned by August Bielowski. ${ }^{97}$ Warschauer usually bought books from antique shops but would not resist bombing German librarians or historical societies in Germany with requests for dispensing duplicates kept in their collections and sending them over to Warsaw.

The Archives of Historical Records was the second such institution to open, in May 1916, for popular use.${ }^{98}$ Contrary to its name, the Archives' collection comprised almost 200,000 manuscripts and fascicules, forming a nineteenth-century documentation of the central authorities of the Duchy of Warsaw and the Kingdom of Poland. On fleeing in 1915, the Russians took away many valuable files, such as the parliamentary statutes from $1815-30$ and the critical sources related to the 'November' (1830-1) and 'January' (1863-4) Insurrections. ${ }^{99}$ During the Russian Partition years, access to the Archives was, again, restricted to the favoured few who usually paid a bribe for

97 See Kaczmarczyk, ‘Działalność niemieckiego zarządu archiwalnego', 117.

98 See BA-Berlin, RdI, no. 119685, 118, 'Generalbericht über die Tätigkeit der Archivverwaltung bei dem Kaiserlich Deutschen Generalgouvernement in den Monaten April bis Juni 1916'.

${ }^{99}$ See Kazimierz Konarski, 'Archiwum Akt Dawnych w Warszawie', in Straty archiwów $i$ bibliotek warszawskich, ii, 72. Apparently, most of the files were eventually returned as part of the vindication action launched pursuant to the 1921 Treaty of Riga; ibidem, 73. 
the privilege. ${ }^{100}$ All the Russian staff employed at the tame with the Archives, with their chief Nikolai Tsykin, escaped in the early days of August 1915; "One elderly servant stayed there, who guarded the dossiers with his Argusian eyes." ${ }^{101}$ Warschauer offered this man to join the new team, and a salary. A more important move, though, was the consent he obtained from Beseler for entrustment of the management of the Archives of Historical Records to Maksymilian Baruch, a Pole; the Jewish background of both men, the German and his Polish colleague, might have had a say in this. It was only in early 1918 that Baruch was employed with the emerging Polish judiciary service and was replaced in the office by Dr Recke, second in rank in the managerial team's hierarchy, who kept the post until the end of the occupation. When the Archives in question were made publicly available, it was visited by eight to ten persons per day, ${ }^{102}$ which was an impressive number, given the context of the time. Apart from historians, Catholic priests were frequent visitors - a group that particularly suffered from the ban on access to the collection; now, they pursued queries in view of historical research or as indispensable for the ongoing handling of administration of their parishes. ${ }^{103}$ After the setting up of the Regency Council in September 1917, high-ranked Polish tax officials sought answers to some of the most topical issues related to taxes or public property. Warschauer met them halfway and was cooperative in lending the documents they considered crucial, thus endearing respect among Polish historians. ${ }^{104}$

The services rendered by the Archives were used by the occupational authorities as well. A number of their offices based in Warsaw subscribed on a regular basis for Warschauer's quarterly reports and, based on what was reported there, requested consulting or dispensation of files of use in resolving the ongoing administrative questions. Requests to the Archives' managers for clarifying genealogical issues came even from the Reich, mainly from noble families. ${ }^{105}$

100 Kaczmarczyk, ‘Działalność niemieckiego zarządu archiwalnego’, 117.

101 Warschauer, Deutsche Kulturarbeit, 287.

102 See BA/MA Freiburg, N 30/29, 'Bericht der Archivverwaltung bei dem Generalgouvernement Warschau über ihre Tätigkeit in den Monaten Januar, Februar und März 1917', 7

103 See BA-Berlin, RdI, no. 119685, 118, 'Generalbericht über die Tätigkeit'.

104 See Kaczmarczyk, 'Działalność niemieckiego zarządu archiwalnego', 117.

105 See BA/MA Freiburg, N 30/29, 'Bericht der Archivverwaltung', 7. 
Warschauer's severest concern was how to duly protect and secure the military archive. Housed at the Vladimir Fort, which was a standalone and somewhat secluded facility, located virtually outside the city, the archive was tempting to thieves - not because of the value of its contents but as a load of wastepaper to make some money on. Night-time burglars would not be scared away by the sentry or by the protection walls: "like moles, they crawled into the site through underground corridors". The precious documents were eventually transported to the Treasury Archive. ${ }^{106}$

The professional protections, cataloguing, and civilised rules of rendering documents accessible, applied by the German Board of Archives: all this established modern standards in the archival art. Beseler's flagship undertaking with respect to importation of German science to Poland, within the 'moral conquest' policy trend, seemed to have fulfilled the hopes pinned on it.

IV

FAILURE OF THE 'MORAL CONQUEST':

WRESTLING FOR PROPERTY RIGHTS TO PRUSSIAN FILES

There was more to the missionary zeal with which the German Board of Archives inventoried and catalogued the archival materials and records in the Generalgouvernement, though. The very first queries confirmed that some valuable sources related to the history of Prussia had been deposited in Warsaw archives; now, the size and importance of the collection found surpassed the German archivists' expectations. In the first place, at the Central Archives as well as the Treasury Archives, Public Prosecutor's Archives and the Archives of Historical Records, they were discovering eighteenth-century documents generated by the administration of Prussia. In the Central Archives, Warschauer counted up 15,000 files or dossiers, with lesser amounts identified in the other archives. ${ }^{107}$ The search for files was pursued across the GGW, mainly in the former sites of Prussian administration, ${ }^{108}$ and even in the adjacent Ludendorff's empire, the Ober Ost. The civil administration was harnessed to join the action.

106 Warschauer, Deutsche Kulturarbeit, 288.

${ }^{107}$ Ibidem; idem, Die Geschichte der Archivverwaltung, 15.

${ }^{108}$ See Die Preußischen Registraturen, fasc. 1, 6. 
Once found, the documents were lent to the Archives Board for cataloguing. The result of the effort was discussed in three publications: (i) tracing the meandering vicissitudes of former Prussian registries; ${ }^{109}$ (ii) discussing in detail the collections of Prussian central authorities' files found in Poland; ${ }^{110}$ and, (iii) analysing 350 manuscripts produced in Prussian provincial centres of power in the Polish territory. ${ }^{111}$

The focus on archiving Prussian records ensued from the intent to take ownership of them. ${ }^{112}$ This approach infringed upon Polish interests and, as a matter of fact, upon the moralische Eroberung. This is why Warschauer, advised to this end by Kehr, ${ }^{113}$ masked the Germans' intentions; while not disclosing his claims with respect to the Prussian records, Warschauer willingly made available Polish-language sources to Polish archivists. As a result, he was glad to conclude that "the two parties supported each other in the research effort, in a friendly atmosphere and with [mutual] respect."114

An overt articulation of the actual intentions of the German managerial team as far as the Prussian files were concerned must have come as a watershed. The turn had been catalysed by a spectacular announcement of the proclamation of a Polish monarchy (5 November 1916) and the establishment of transitional Polish authorities, including a departmental body to be responsible for Polish archives and archival collections. ${ }^{115}$ The new committee requested Beseler to "instantaneously take over all Polish archives", together with their collections, from German hands (1 March 1918). ${ }^{116}$ This coincided

109 Ibidem.

${ }^{110}$ Die Preußischen Registraturen, fasc. 2.

111 Warschauer, 'Einleitung'.

112 See Lehr, 'Die "Rückforderung”, 50-1.

113 Ibidem, 51.

114 Warschauer, Die Geschichte der Archivverwaltung, 15.

115 Marceli Handelsman was made head of this office, whilst Wierzbowski, Director of the Central Archives, who showed his pro-Russian bias, was completely ignored and not even made a member of the committee; thus, he assumed an inimical position against it. Once established, the team took first steps to save the Prussian registries from getting taken away to Berlin. See Antoni Rybarski, 'Centralny zarząd archiwalny odrodzonej Rzeczpospolitej Polskiej', Archeion, i (1927), 4.

116 The Minister of Religions and Public Education to the President of the Council of Ministers (16 February 1918); Rybarski, 'Centralny zarząd archiwalny', 8. 
with a turn in the attitude of the Governor-General, who renounced his original legalistic stance and, from autumn 1917 onwards, showed increased understanding for the option to transfer the Prussian archives to Berlin. ${ }^{117}$ Beseler was influenced by a growing frustration in face of the political demands of his Polish subjects and increasing sensitivity to the needs of the German minority in a Poland-to-be. ${ }^{118}$ The 'moral conquest' project was rocking on its foundations as its flagship aspect - the importation of civilizational achievements of German science - grew vulnerable as the Poles began guessing the intentions of their German partners. Polish archivists breathed down their German colleagues' necks. The climate in the archives cooled down substantially, and public recognition of Warschauer's scientific accomplishments faded amongst the Poles. ${ }^{119}$

The collapse of the 'moral capture' policy in the GGW, as far as exporting German science to Poland went, was de facto announced by Beseler himself: He was the first to have officially articulated the German claims with respect to the Prussian records, in reply to a request from the Polish archival management board. Beseler rendered his consent for supplying them with the archives and their collections (within the General Government) dependent on their meeting two conditions. ${ }^{120}$ One was to form the (aforementioned) German historical institute, to be modelled after the Rome-based institution, in order for it to continue after the war the work initiated by the Archives Board, the Polish party being reassured that a corresponding institute would open in Berlin. The other postulate was for the two parties to come to an arrangement regarding the dispensation to the Germans of the records now deposited in Polish archives but once being property of the German-language countries forming the Hohenzollern empire. ${ }^{121}$ This concerned, in particular,

117 See Lehr, 'Die "Rückforderung”', 53.

118 See AAN, no. 916, 'Beseler an Kaiser Wilhelm II., 13. Oktober 1917’.

119 See Kaczmarczyk, ‘Działalność niemieckiego zarządu archiwalnego', 117.

120 The deadline for transferral of custody over the archives to the Poles was to be early December 1918, though it was assumed that, in spite of the German civil administration of GGW having been dissolved, the German management of the archives would continue functioning at least until the end of 1918. See BA/MA Freiburg, N 30/25, 'Schlussprotokoll über die Beratungen der Vertreter der Okkupationsmächte betreffend die Übergabe der Verwaltung an den polnischen Staat'.

${ }^{121}$ Rybarski, 'Centralny zarząd archiwalny', 8. 
the central Prussian registries from after 1795, which, "in line with their provenance, form the Prussian, rather than a Polish, archival body". ${ }^{122}$

It was these records that were bargained over for the whole year 1918, until the last day of the German occupation, by Polish and German archivists. ${ }^{23}$ The paradigm of the GGW authorities' behaviour and priorities was made apparent on this occasion: they aimed at discounting the asymmetric positions of the settling parties. As was the case with the other key negotiations with exponents of the (re-)emerging Poland - for granting the Evangelical Church of the Augsburg Confession an ecclesial status, or ensuring school autonomy to the German minority in Poland to emerge - also this time the German authorities negotiated from a position of strength. Hutten-Czapski warned against this in his letter to Kehr: "I should consider disastrous the discounting of our strength in Warsaw."124 But his words turned into an ominous prophecy. The Germans resorted many a time to a strategy of strength and coercion; probably the most spectacular in this respect was their use of an argument derived from the Treaty of Brest-Litovsk (successful for them as it was), whereby the German Empire had taken over the rights to Russian property in its entirety, which extended to the archives deposited in Poland. The merits of this argument was clearheadedly described by Hutten-Czapski as a "pure nonsense". ${ }^{125}$ Yet, a clarifying memo sent by the Count suffered the fate of similar warnings, numerous as they have been in the history of mankind. If it ever reached the ears of the Berlin decision-makers, it was put aside and impressed them in no way, while the further history confirmed the Count's words.

This is how Beseler's 'moral conquest' programme finally collapsed in the sphere of science, for a successful strategy of seducing the weaker partner with a soft-power offer is based on making subtle suggestions that might generate acceptance (of these suggestions and of the seduction), rather than on using power to back him into a corner. The bargaining that headed for a blind alley was only interrupted by the fall of the Hohenzollern empire, Beseler's deposition

122 See Warschauer, Deutsche Kulturarbeit, 313.

123 For a detailed account of this bargaining, see Lehr, 'Die "Rückforderung"'.

${ }^{124}$ Hutten-Czapski, Sechzig Jahre, 475.

125 Ibidem. "These records", he added, "are, naturally, property of the State of Poland". 
as the ruler in Warsaw, and the dissolution of the German Board of Archives, ${ }^{126}$ forcing a complete capitulation of its director. In the dramatic circumstances of the 11 November 1918 events, Warschauer transmitted all the archives into Polish hands. ${ }^{127}$ A record co-signed by him and representatives of the Polish Ministry decided that each archive be provided to them separately.

The Poles really entered into possession of the archives by the handing in of the key and the fixing on the entrance door of a bill reading 'The Archive of the State of Poland' [Archiwum Państwa Polskiego]. Adolf Warschauer, now the former Director of the Imperial German Board of Archives, left the Polish capital on 15 November 1918, travelling in a unheated freight wagon with a hand luggage and 1,000 marks of cash, ${ }^{128}$ thus sharing in the lot of the numerous officers and servants of the German Civil Board.

\section{$\mathrm{V}$ \\ CONCLUSION}

The protection and the stocktaking of the records was the merit of the Board of Archives; the standardised availability of archival resources to Polish researchers and unrestrained access to public archives marked an upgrade of the once-Russian archival system in Poland. These achievements are nowise diminished by the fact that the presence of a German managerial team in charge of the archives within the General Government enabled the German Empire to demonstrate its scientific power as a 'transmission belt' for the moralische Eroberung programme.

Yet, the export of the German model of archival system into Poland by way of the imperial Board of Archives being installed in Warsaw, all in order to increase the superpower's prestige and

${ }^{126}$ After the GGW's Civil Board was dissolved in December 1918 and all the archives provided to the re-established Poland, the German Board of Archives was to stay in Warsaw "for some time", which probably meant the end of 1919, in order to help complete all the publications then still in statu nascendi; see BABerlin, RdI, no. 119685, 193 ff., 'Die Auflösung der Archivverwaltung, Bericht Adolf Warschauers' [no date specif.].

${ }^{127}$ For an account of the course of the day, see Warschauer, Deutsche Kulturarbeit, 316.

${ }^{128}$ Ibidem, 317. 
legitimacy of the authority it wielded, was combined by the occupiers with the activity that served their particular interests in Congress Poland: namely, laying claims with respect to the archives of Prussian origin, stored therein at the time. This did not, as yet, annihilate the 'moral conquest' scheme as far as importation of German science and organisation to Poland was concerned. The final episode was marked by the course of the bargaining over the disputable documents, where the German party negotiated from a position of strength. As was proved by the developments of 11 November 1918 in Warsaw, the German occupational authority was prone to put the Polish party on an equal footing in the rights to the archives only when its own position started swaying and creaking most dangerously.

Germany's 'civilizational mission' ended where it collided against the country's own particular interests: the paradigm of action which, appearing in the other areas of Beseler's policy in the GGW, was at odds with the 'moral conquest' project, did correspond, all in all, with the superpower's colonial perspective against a subordinate country. Thus, in the GGW - similarly to what happened during the German-Polish bargaining for autonomy for the German school system in the reborn Poland, or the negotiations for the status of the Lutheran Church ${ }^{129}$ - it was the German party to impose the conditions of the parley, assigning the Polish counterparty a mediocre position. "The position of Poland in Europe [could not] be shaped according to what the Poles might be wishing to have": ${ }^{130}$ such was the guiding slogan for Beseler. Kehr explained this in a rather expected fashion: in dubious situations, Prussian interests take prevalence over Polish interests. Therefore, Kehr, Beseler, and the Prussian Ministry of Interior would not resist using force in the dispute on the succession of archival goods.

The fierce Polish-German dispute over the takeover of Prussian registries was, paradigmatically, an inherent element of succession of archives between the collapsing multiethnic monarchies and the nation-states emerging out of them after the First World War. As a matter of fact, it was part of a broader phenomenon that relativised the fierceness of the German-Polish wrestling. Austria and Hungary were involved in strenuous negotiation for their archives, which they had shared after 1867. The compromise they came to (the Badener

129 See Stempin, Próba 'moralnego podboju', 305-38, 488-501.

130 AAN, no. 916, 'Beseler an Kaiser Wilhelm II. vom 13. Oktober 1917'. 
Archivabkommen, 28 May 1926) provided that the archives remain, indivisible, in Vienna but opened an opportunity for a common heritage of both countries (patrimoine intellectuel), with Hungary allowed to manage and use it. ${ }^{131}$ As for Czechoslovakia, Austria had to transfer to it the archives with records related to Czechoslovak statehood. ${ }^{132}$

Comparing, however, the methodology applied by the GGW authorities against the Nazi practices in Poland twenty years later, one identifies a shocking divide between them - including in the micro-area of management of archives and cultural goods amassed in them. ${ }^{133}$ During the Second World War all the Prussian registries were deported to Berlin without ceremony. As opposed to those most distressing days, the activities of the imperial Board of Archives in the First World War years was based on (however limited) collaboration between German and Polish archivists. Not on equal footing, they would nonetheless sit at a shared table and discuss things. Twenty years later, Polish archivists were not even admitted to the table; almost thirty eventually lost their lives. ${ }^{134}$ The Nazis relied on decretive lawlessness whereas the GGW authorities, in the years 1915-18, respected the international law.

This difference reflects a broader phenomenon: insofar as the late nineteenth and early twentieth century saw the emergence of national, state-related, or imperial identity in Europe, ${ }^{135}$ the totalitarian systems completely denied these developments in the 1930s and afterwards. ${ }^{136}$

trans. Tristan Korecki

131 See Michael Silagi, 'Die internationalen Regelungen zum Archivgut der Habsburgermonarchie nach 1918. Zum Schicksal von Archiven beim Staatzerfall', Südostforschungen, lv (1996), 311-33.

132 See Yves Huguenin-Bergenat, Kulturgüter bei Staatensukzession: Die internationalen Verträge Österreichs nach dem Zerfall der österreichisch-ungarischen Monarchie im Spiegel des aktuellen Völkerrechts (Berlin, 2010), 130-40.

${ }^{133}$ See Eugeniusz C. Król, 'Besatzungsherrschaft in Polen im Ersten und Zweiten Weltkrieg. Charakteristik und Wahrnehmung', in Thoß and Volkmann (eds.), Erster Weltkrieg - Zweiter Weltkrieg, 577-91.

${ }^{134} \mathrm{Cf}$. the commemorative plaque at the AGAD.

135 See Bernd Estel, Nation und nationale Identität: Versuch einer Rekonstruktion (Wiesbaden, 2002).

136 See Alfons Söllner, Ralf Walkenhaus, and Karin Wieland, Totalitarismus: Eine Ideengeschichte des 20. Jahrhunderts (Berlin, 2010). 


\section{SELECTED BIBLIOGRAPHY}

Barth Boris and Osterhammel Jürgen (eds.), Zivilisierungsmission (Konstanz, 2005). Conze Werner, Polnische Nation und deutsche Politik im Ersten Weltkrieg (Köln and Graz, 1958).

Fitschen Thomas, Das rechtliche Schicksal von staatlichen Akten und Archiven bei einem Wechsel der Herrschaft über Staatsgebiet (Baden-Baden, 2004).

Grysińska-Jarmuła Katarzyna, Hrabia Bogdan Hutten-Czapski (1851-1937). Żotnierz, polityk $i$ dyplomata (Toruń, 2011).

Kaczmarczyk Kazimierz, 'Działalność niemieckiego zarządu archiwalnego w latach 1915-1918', Archiwum Komisji Historycznej Akademii Umiejętności, i (xiii) (1923), 114-23.

Lehr Stefan, 'Die "Rückforderung” polnischer Archivalien', in Dietmar Neutatz and Volker Zimmermann (eds.), Die Deutschen und das östliche Europa. Aspekte einer vielfältigen Beziehungsgeschichte. Festschrift für Detlef Brandes zum 65. Geburtstag (Essen, 2006), 47-66.

Lehr Stefan, 'Pläne für ein Deutsches Historisches Institut in Warschau im Ersten Weltkrieg', Zeitschrift für Ostmitteleuropa-Forschung, lvi, 4 (2007), 594-602.

Lemons Walker Kathy, Chinese Modernity and the Peasant Path: Semi-Colonialism in the Northern Yangzi Delta (Stanford, 1999).

Metzinger Udo, Hegemonie und Kultur: die Rolle der kulturellen soft-power in der US-Außenpolitik (Frankfurt am Main et al., 2005).

Mühlhahn Klaus, Herrschaft und Widerstand in der 'Musterkolonie' Kiautschou. Interaktionen zwischen China und Deutschland 1897-1914 (München, 2000).

Rohrbach Paul, Der deutsche Gedanke in der Welt (Düsseldorf and Leipzig, 1912).

Stempin Arkadiusz, Próba 'moralnego podboju' Polski przez cesarstwo niemieckie w latach I wojny światowej (Warszawa, 2014).

Warschauer Adolf, Deutsche Kulturarbeit in der Ostmark. Erinnerungen aus vier Jahrzehnten (Berlin, 1926).

Warschauer Adolf, Geschichte der Archivverwaltung bei dem Deutschen Generalgouvernement Warschau (Berlin, 1919).

Weiser Johanna, Geschichte der preußischen Archivverwaltung und ihrer Leiter. Von den Anfängen unter Staatskanzler von Hardenberg bis zur Auflösung im Jahre 1945 (Köln, 2000).

Arkadiusz Stempin - 20th century history; professor at the Tischner European University, Cracow; e-mail: arkadiusz.stempin@pluto.uni-freiburg.de 